\title{
Molecular characterization of Salmonella spp. isolates from river and dam water, irrigated vegetables, livestock, and poultry manures in Jordan
}

\author{
Yaser H. Tarazi ${ }^{1}$, Abdallah F. Al Dwekat ${ }^{1}$ (D) and Zuhair Bani Ismail²
}

1. Department of Veterinary Basic Sciences, Faculty of Veterinary Medicine, Jordan University of Science and Technology, Irbid 22110, Jordan; 2. Department of Veterinary Clinical Sciences, Faculty of Veterinary Medicine, Jordan University of Science and Technology, Irbid 22110, Jordan.

Corresponding author: Yaser $\mathrm{H}$. Tarazi, email: tarazi@just.edu.jo

Co-authors: AFA: aldwekat@gmail.com, ZBI: zuhair72@just.edu.jo,

Received: 09-10-2020, Accepted: 16-02-2021, Published online: 31-03-2021

doi: www.doi.org/10.14202/vetworld.2021.813-819 How to cite this article: Tarazi YH, Al Dwekat AF, Ismail ZB (2021) Molecular characterization of Salmonella spp. isolates from river and dam water, irrigated vegetables, livestock, and poultry manures in Jordan, Veterinary World, 14(3): 813-819.

\begin{abstract}
Background and Aim: Salmonellosis is an important food-borne and zoonotic disease with high morbidity and mortality rates. The objectives of this study were to isolate, serotype, and genetically characterize Salmonella spp. from Zarqa river and King Talal dam waters, vegetables irrigated by such waters, and manure of poultry and livestock farms located in the Zarqa river basin in Jordan. In addition, certain virulence factors and antimicrobial resistance patterns of isolated Salmonella strains were determined.
\end{abstract}

Materials and Methods: A total of 250 samples were cultured using routine microbiological methods. Suspected Salmonella spp. were identified based on colony morphology and confirmed using biochemical and molecular methods. Virulence genes including invA, stn, and $p C T$ plasmid were detected using multiplex PCR. Phylogenetic analysis was performed using pulsed-field gel electrophoresis (PFGE).

Results: In total, 32/250 (12.8\%) Salmonella spp. isolates were recovered from different sources. Of these, the most common serotype was Salmonella subspecies 1 (23 isolates), followed by Salmonella enterica serovar Typhimurium (4 isolates), Salmonella enterica serovar Typhi (3 isolates), and finally Salmonella enterica serovar Enteritidis (2 isolates). The PFGE indicated that Salmonella enterica serovar Typhimurium isolated from poultry manure and from parsley were closely related (84.6\%). Salmonella enterica serovar Enteritidis isolated from the dam water was closely related to Salmonella enterica serovar Enteritidis isolated from spearmint (73.8\%). Salmonella enterica serovar Typhi isolated from the river and dam water were $100 \%$ related to Salmonella enterica serovar Typhi isolated from lettuce. In the antimicrobial sensitivity test, 14 out of 32 (43.8\%) isolated Salmonella strains were resistant to two or more of the major antimicrobial agent groups. However, the majority of isolates were sensitive to ceftriaxone, ciprofloxacin, cefuroxime, and gentamicin $(97 \%, 93.8 \%$, and $87.5 \%, 84.4 \%$, respectively). All isolates were resistant to erythromycin and amoxicillin.

Conclusion: Results of this study indicate a serious potential threat to public health associated with consuming leafy green vegetables grown on the banks of Zarqa river and its dam because of widespread Salmonella spp. contamination. Appropriate monitoring of irrigation water must be applied to reduce the possibility of cross-contamination.

Keywords: Salmonella spp., zoonosis, contaminated river and dam waters, vegetables.

\section{Introduction}

Vegetables are one of the most popular raw materials of food because of their convenience and consumer acceptability [1-4]. In the last few decades, the demand for fresh leafy green vegetables has steadily increased due to consumer's perceived benefits of healthy food for healthier lifestyle [1-4]. Unfortunately, leafy green vegetables are commonly contaminated by various food-borne microorganisms at pre-harvesting, harvesting, or post-harvesting $[3,4]$.

Copyright: Tarazi, et al. Open Access. This article is distributed under the terms of the Creative Commons Attribution 4.0 International License (http://creativecommons.org/licenses/by/4.0/), which permits unrestricted use, distribution, and reproduction in any medium, provided you give appropriate credit to the original author(s) and the source, provide a link to the Creative Commons license, and indicate if changes were made. The Creative Commons Public Domain Dedication waiver (http://creativecommons.org/ publicdomain/zero/1.0/) applies to the data made available in this article, unless otherwise stated.
Worldwide, there has been a sharp increase in reported incidences of food-borne illnesses attributed to consumption of raw parsley, lettuce, spearmint, and spinach $[3,4]$. Sources of contamination are usually soil, irrigation water, organic-based fertilizers, and direct contact with animal feces [1-4].

Salmonellosis is considered as one of the most important food-borne and zoonotic diseases causing serious illnesses in humans and animals $[5,6]$. The primary sources of Salmonella organisms in food, including leafy green vegetables, are irrigation using surface water in rivers and dam lakes and the use of organic fertilizers made from poultry or livestock manure $[7,8]$. The most common food-borne pathogenic Salmonella strains have been Salmonella enterica serovar Typhimurium DT104, Salmonella enterica serovar Enteritidis, and Salmonella subspecies I [9-11]. 
In Jordan, the Zarqa river and its associated dam (King Talal dam) are major sources of surface water which are mainly used to irrigate vegetables grown alongside its banks and as a drinking water for livestock in the region. The river and dam are notoriously prone to contamination by organic and non-organic material because of their proximity to livestock farms, industrial plants and most importantly, the construction of a major waste water treatment plant where treated wastewater is discharged to the river and ultimately into the dam. The presence of Salmonella spp. in the water of the Zarqa river and King Talal dam as well as the prevalence of this important food-borne and zoonotic pathogen in the manure of poultry and livestock and on leafy vegetables in this region has not been studied before. Therefore, the objectives of this study were to isolate, serotyping, and genetically characterize Salmonella spp. from Zarqa river and King Talal dam water samples, vegetables irrigated by such waters, and manure of poultry and livestock farms located in the Zarqa river basin. In addition, certain virulence factors and antimicrobial resistance patterns of isolated Salmonella strains were determined.

\section{Materials and Methods}

\section{Ethical approval and Informed consent}

No institutional ethical approvals were required in this study since it involved no animal use. However, written and signed consents were obtained from livestock farm owners and vegetable farmers before manure and vegetable samples were collected.

\section{Study period and location}

The study was conducted from June 2015 to May 2016. Laboratory analysis was carried out in the Microbiology Research Laboratory, Faculty of Veterinary Medicine, Jordan University of Science and Technology.

\section{Sample collection}

A total of 250 samples (water, vegetables, poultry, and livestock manure) were collected. The sampled vegetables $(\mathrm{n}=100 ; 25$ each) were parsley, lettuce, Eruca sativa, and spearmint. Water samples $(\mathrm{n}=50)$ were directly taken from the river and dam (25 each) from different locations up and downstream. The manure samples $(\mathrm{n}=100 ; 25$ each) were from poultry, dairy cattle, sheep, and goat farms. All vegetable and manure samples were collected from farms that are located on both sides of the river and used water for irrigation or drinking for animals from the river or from the dam. Fresh green leaves and vegetable samples were collected using sterile forceps and scissors and put into sterile polyethylene bags. For each manure sample, $100 \mathrm{~g}$ of manure were collected from 5 points in each farm, one sample from the center, and four from periphery of the farm by sterile spatula, mixed, and placed in a sterile fecal cup container [12].

\section{Bacterial isolation and identification}

To culture vegetable samples, a $25 \mathrm{~g}$ of fresh sample was homogenized with $225 \mathrm{~mL}$ of buffered peptone water (BPW; Oxoid) in a stomacher (Seward Stomacher, England) and incubated at $37^{\circ} \mathrm{C}$ for $18 \mathrm{~h}$. Then, 2 aliquots $(0.1 \mathrm{~mL})$ were inoculated in Rappaport Vassiliadis soy peptone (RVS) broth (Oxoid) and Tetrathionate broth (TTB; Oxoid) and incubated at $41.5^{\circ} \mathrm{C}$ and $37^{\circ} \mathrm{C}$, respectively, for $24 \mathrm{~h}$. Then, $10 \mu \mathrm{L}$ aliquots from RVS and TTB broths were inoculated on Xylose Lysine Deoxycholate (XLD; Oxoid) and on Brilliant Green agar (BGA; Oxoid) and incubated at $37^{\circ} \mathrm{C}$ for $24 \mathrm{~h}$.

For water samples, $1 \mathrm{ml}$ of each water sample was inoculated into $10 \mathrm{ml}$ BPW (Oxoid) and incubated at $37^{\circ} \mathrm{C}$ for $18 \mathrm{~h}$. Then, two aliquots $(0.1 \mathrm{~mL})$ were inoculated in RVS broth (Oxoid) and TTB broth (Oxoid) and incubated at $41.5^{\circ} \mathrm{C}$ and $37^{\circ} \mathrm{C}$, respectively, for $24 \mathrm{~h}$. Then, $10 \mu \mathrm{L}$ aliquots from RVS and TTB broths were inoculated on XLD (Oxoid) and on BGA (Oxoid) and incubated at $37^{\circ} \mathrm{C}$ for $24 \mathrm{~h}$.

For manure samples, $1 \mathrm{~g}$ of each sample was inoculated into $10 \mathrm{ml} \mathrm{BPW} \mathrm{(Oxoid)} \mathrm{and} \mathrm{incubated} \mathrm{at}$ $37^{\circ} \mathrm{C}$ for $18 \mathrm{~h}$. Then, two aliquots $(0.1 \mathrm{~mL})$ were inoculated in RVS broth (Oxoid) and TTB broth (Oxoid) and incubated at $41.5^{\circ} \mathrm{C}$ and $37^{\circ} \mathrm{C}$, respectively, for $24 \mathrm{~h}$. Then, $10 \mu \mathrm{L}$ aliquots from RVS and TTB broths were inoculated on XLD (Oxoid) and on BGA (Oxoid) and incubated at $37^{\circ} \mathrm{C}$ for $24 \mathrm{~h}$.

Presumptive identification of Salmonella spp. was made initially based on colony morphology and Gram staining characteristics. Confirmation was then achieved by biochemical methods (RapID ONE System, Thermo Fisher, USA) according to manufacturer's instructions. Pure colonies of the isolates were then transferred into slants of nutrient agar (Oxoid), incubated at $37^{\circ} \mathrm{C}$ for $24 \mathrm{~h}$ and stored as stock cultures until further use [12].

For control, the reference strains obtained from the American Type Culture (ATCC) 14028 (Salmonella enterica serovar Typhimurium), ATCC 13076 (Salmonella enterica serovar Enteritidis) and National Collection of Type Cultures (NCTC) 5760 (Salmonella enterica serovar Typhi), and NCTC 8385 (Salmonella subspecies I) were used in the study.

\section{DNA extraction}

DNA was extracted by the boiled cell method [13]. Briefly, $1 \mathrm{~mL}$ of each isolate broth was centrifuged for $3 \mathrm{~min}$ at 15,000 g. The supernatant was then discarded and the pellet was resuspended in $500 \mu \mathrm{L}$ of sterile distilled water and vortexed. The cell suspension was boiled for $10 \mathrm{~min}$ and immediately cooled at $-20^{\circ} \mathrm{C}$ for $10 \mathrm{~min}$, followed by centrifugation at $15,000 \mathrm{~g}$ for $3 \mathrm{~min}$. The supernatant was transferred into clean tubes to be used as the DNA template solution for the optimization of the multiplex PCR.

\section{Detection of virulence factors}

PCR was performed to detect Salmonellaspecific invA gene (responsible for cell invasion), 
enterotoxin gene $(s t n)$, and the $p C T$ plasmid gene using commercially available primers (Table-1). The PCR reaction solution was made of the following components: $0.5 \mu \mathrm{L}$ of each primer, $12.5 \mu \mathrm{L}$ Dream Taq master mix (Promega, USA), and $3 \mu \mathrm{L}$ template DNA, nuclease-free water were then added to reach total volume of $25 \mu \mathrm{L}$. For negative control, sterile distilled water instead of the template DNA solution was included in three wells in each PCR assay. The PCR machine (Thermal Cycler; Applied Biosystems, CA) program was set at $5 \mathrm{~min}$ at $94^{\circ} \mathrm{C}$ before 35 cycles of $1 \mathrm{~min}$ at $94^{\circ} \mathrm{C}$, annealing temperature at $55^{\circ} \mathrm{C}$ for stn and invA, extension at $72^{\circ} \mathrm{C}$ for $1 \mathrm{~min}$, and a final extension of $10 \mathrm{~min}$ at $72^{\circ} \mathrm{C}$. For $p C T$ plasmid gene, the same conditions were used except the annealing temperature was $60^{\circ} \mathrm{C}$ for $1 \min [7,14]$. All PCR products were analyzed by gel electrophoresis in $2 \%$ agarose gels and stained with $0.5 \mu \mathrm{g} / \mathrm{mL}$ ethidium bromide, and then visualized under ultraviolet (UV) light [15]. A 100-bp ladder was used as a marker in all electrophoresis gel runs.

\section{Serotyping of Salmonella isolates}

Serotyping of Salmonella isolates was performed using multiplex PCR optimized for the detection of Salmonella enterica serovar Typhimurium, Salmonella enterica serovar Enteritidis, Salmonella enterica serovar Typhi, and Salmonella subspecies I using the primer pairs as shown in Table-2. The primer pairs were evaluated in the final multiplex PCR reaction using three repetitions to ensure reproducibility of the assay. The PCR reaction was made of a $25 \mu \mathrm{L}$ containing $0.5 \mu \mathrm{L}$ of each primer pair, $12.5 \mu \mathrm{L}$ Dream Taq master mix (Promega, USA), $3 \mu \mathrm{L}$ templates DNA, and nuclease-free water to reach the total volume $25 \mu \mathrm{L}$. For negative control, sterile distilled water instead of the template DNA solution was included in three wells in each PCR assay. The PCR machine

Table-1: Sequences of primers of various virulence genes used in the study to characterize Salmonella isolates from River and Dam water samples, irrigated vegetables, and poultry and livestock manure samples in Jordan $[7,14]$.

\begin{tabular}{llc}
\hline Gene & sequence & Size (bp) \\
\hline stn & F- TTGTGTCGCTATCACTGGCAACC & 617 \\
& R-ATTCGTAACCCGCTCTCGTCC & \\
invA & F- GTGAAATATCGCCACGTTCGGGCAA & 284 \\
& R- TCATCGCACCGTCAAAGGAACC & \\
pCT & F- CATTGTATCTATCTTGTGGG & 428 \\
& R-GCATTCCAGAAGATGACGTT & \\
\hline
\end{tabular}

(Thermal Cycler; Applied Bio systems, CA) program was set at $94^{\circ} \mathrm{C} 3 \mathrm{~min}$, annealing temperature $57^{\circ} \mathrm{C}$ $30 \mathrm{~s}$ and $72^{\circ} \mathrm{C} 30 \mathrm{~s}$, for $30 \mathrm{cycles}$, and final extension $72^{\circ} \mathrm{C} 3 \mathrm{~min}$ and was stored at $4^{\circ} \mathrm{C}$ until used. All PCR products were analyzed by gel electrophoresis in $2 \%$ agarose gels and stained with $(0.5 \mu \mathrm{g} / \mathrm{mL})$ ethidium bromide, and then visualized under UV light [15]. A 100 -bp ladder was used as a marker in all electrophoresis gel runs.

\section{Antimicrobial sensitivity test}

The antimicrobial sensitivity test was performed using the agar disk diffusion method on MuellerHinton agar plates (Oxoid) [16]. The inoculated plates were incubated at $35^{\circ} \mathrm{C}$ for $24 \mathrm{~h}$. A total of 14 antibiotics were tested using commercially available disks (Thermo Fisher) including ciprofloxacin $(5 \mathrm{mg})$, cefuroxime $(30 \mathrm{mg})$, sulfamethoxazole/trimethoprim $(23.75 / 1.25 \mathrm{mg})$, tetracycline $(30 \mathrm{mg})$, nalidixic acid (30 mg), chloramphenicol (30 mg), ceftriaxone (30 $\mathrm{mg})$, kanamycin $(30 \mathrm{mg})$, penicillin (10 IU), gentamicin $(10 \mathrm{mg})$, oxytetracycline $(30 \mathrm{mg})$, streptomycin $(10 \mathrm{mg})$, erythromycin $(15 \mathrm{mg})$, and amoxicillin (20 mg). Results of the sensitivity test were classified as sensitive, intermediate, or resistant according to the diameter of the inhibition zone according to the National Committee of Clinical Laboratory Standards guidelines [16].

\section{Pulsed field gel electrophoresis (PFGE) Bacterial culture preparation}

All isolates were subcultured on tryptone soya agar plates (Oxoid) and incubated at $37^{\circ} \mathrm{C}$ for $18 \mathrm{~h}$ to obtain a confluent growth. All colonies were removed from the surface of TSA plates using sterile polyester fiber applicator moistened with sterile cell suspension buffer (CSB; $100 \mathrm{mM}$ Tris: $100 \mathrm{mM}$ Ethylenediaminetetraacetic acid [EDTA], $\mathrm{pH}$ 8.0) and transferred into sterile tubes containing $2 \mathrm{~mL}$ of CSB. The concentration of each cell suspension was adjusted to a value correspondent to an absorbance value of 1.3-1.4 O.D. at $610 \mathrm{~nm}$ wavelength using a spectrophotometer (Jenway, UK). A $400 \mu \mathrm{L}$ aliquot of each adjusted cell suspension was then transferred to a sterile microcentrifuge tube containing $20 \mu \mathrm{L}$ of proteinase $\mathrm{K}(20 \mathrm{mg} / \mathrm{mL}$ stock) then the $400 \mu \mathrm{L}$ of melted 1\% SeaKem Gold agarose (Sigma, USA) prepared in TE buffer (10 mM Tris: $1 \mathrm{mM}$ EDTA, pH 8.0) was added and the mixture was mixed by gentle

Table-2: Primers used in the serotyping of Salmonella isolates by multiplex PCR [15].

\begin{tabular}{llc}
\hline Serotype & Sequence & Size (bp) \\
\hline Salmonella enterica serovar Typhi & F- TTACCCCACAGGAAGCACGC & 203 \\
Salmonella enterica serovar & R- CTCGTTCTCTGCCGTGTGGG & 310 \\
Typhimurium & F- AACAACGGCTCCGGTAATGAGATTG & 559 \\
Salmonella enterica serovar & R- ATGACAAATCTTGTTCTGAAGATCG & 137 \\
Enteritidis & F- GGATAAGGGATCGATAATTGCTCAC & 137 \\
Salmonella subspecies I & R- GGACTTCCAGTTATAGTAGGTGGCC & \\
& F- GGTGGCCTCGATGATTCCCG & \\
\hline
\end{tabular}


pipetting up and down (melted agarose was kept at $5560^{\circ} \mathrm{C}$ in water bath). After that, the mixture was dispensed into the wells of PFGE plug and the plugs were allowed to solidify at $4^{\circ} \mathrm{C}$ for $5 \mathrm{~min}$. The plugs were then removed from the molds and placed in a $5 \mathrm{~mL}$ tube containing $5 \mathrm{~mL}$ of Cell Lysis Buffer (CLB; $50 \mathrm{mM}$ Tris, $50 \mathrm{mM}$ EDTA, pH 8.0), 1\% Sarcosyl (Sigma), and proteinase $\mathrm{K}(0.1 \mathrm{mg} / \mathrm{mL}$ proteinase $\mathrm{K})$ and incubated at $54^{\circ} \mathrm{C}$ in shaker water bath for $2 \mathrm{~h}$. After that, the plugs were washed 2 times with sterile ultrapure water pre heated to $50^{\circ} \mathrm{C}$ for $15 \mathrm{~min}$ in a water bath and followed by four washes with sterile TE buffer (TE; $10 \mathrm{mM}$ Tris: $1 \mathrm{mM}$ EDTA, pH 8.0) preheated to $50^{\circ} \mathrm{C}$ for $15 \mathrm{~min}$. The plugs were stored in TE buffer at $4^{\circ} \mathrm{C}$ until used.

\section{Restriction digestion with XbaI enzyme}

Two-millimeter-wide piece was cut from each of the plugs and added to a tube containing $200 \mu \mathrm{L}$ of a $1 \times$ dilution of the restriction buffer and incubated at $37^{\circ} \mathrm{C}$ water bath for 5-10 min. The restriction buffer was replaced with $200 \mu \mathrm{L}$ of $X b a I$ restriction enzyme and incubated for $2 \mathrm{~h}$ at $37^{\circ} \mathrm{C}$; then the restriction mixture was replaced with $200 \mu \mathrm{L}$ of $0.5 \times$ Tris borate EDTA (TBE; prepared from 10-TBE containing $0.89 \mathrm{M}$ Tris borate, $0.02 \mathrm{M}$ EDTA, $\mathrm{pH} 8.3$ ) and allowed to stand for 5 min to saturate the plug slices with electrophoresis running buffer.

\section{Electrophoresis conditions and casting of the aga- rose gel}

The 1\% SKG gels (Sigma) plugs were loaded in the electrophoreses wells and the electrophoresis conditions for Salmonella spp. were set as follows: Initial switch time of $2.2 \mathrm{sec}$ and a final switch time of $63.8 \mathrm{~s}$ (based on a fragment range of 30-700 kb) and electrophoresis run time of 18-19 h. After the electrophoresis was completed, the gels were stained with $400 \mathrm{~mL}$ of ethidium bromide solution (dilute $40 \mu \mathrm{L}$ of ethidium bromide stock solution [10 mg/mL] with $400 \mathrm{~mL}$ of distilled water for 20-30 min), then the gel was de-stained in $500 \mathrm{~mL}$ distilled water for $60-90 \mathrm{~min}$, and then the image was captured using video gel documentation system (Bio-Rad, USA). The image was then analyzed using the Jaccard band coefficient to calculate the similarities between the lanes, with a tolerance of $0.625 \%$ and the relatedness between isolates was determined using BioNumerics version 2 Software (Applied Maths, Belgium).

\section{Results}

Out of 250 samples, $32(12.8 \%)$ isolates were positively confirmed as Salmonella spp. using biochemical and molecular methods. Of these, 16 isolates $(50 \%)$ were from the river, dam, spearmint, and lettuce (4 each); three isolates $(9.38 \%)$ were from E. sativa, two isolates (6.25\%) from parsley, seven isolates $(21.87 \%)$ from poultry manure, three isolates $(9.38 \%)$ from goat manure, one isolate $(3.12 \%)$ from sheep manure, and no isolates were cultured from dairy cow manure. According to the source of the samples, Salmonella spp. were recovered in $16 \%$ $(8 / 50), 11 \%(11 / 100)$, and $13 \%(13 / 100)$ from the river and dam water combined, poultry, and livestock manure combined and vegetables combined, respectively. All isolates were positive for the invA and stn genes, except 1 isolate from goat manure which was negative for stn gene. None of the isolates carried the $p C T$ plasmid gene.

Serotyping indicated that the most common serotype was Salmonella subspecies I (23 isolates), followed by Salmonella enterica serovar Typhimurium (four isolates), Salmonella enterica serovar Typhi (three isolates), and finally Salmonella enterica serovar Enteritidis (two isolates). Table-3 shows the distribution of Salmonella serotypes according to the sample source in the studied area. The PFGE analysis revealed that isolated strains were of two major clusters with all Salmonella enterica serovar Typhi located in one cluster while all Salmonella enterica serovar Typhimurium and Salmonella enterica serovar Enteritidis isolates were located in the second cluster (Figure-1). The PFGE indicated that Salmonella enterica serovar Typhimurium isolates from poultry manure and from parsley were closely related (84.6\%). Salmonella enterica serovar Enteritidis isolated from the dam was closely related to Salmonella enterica serovar Enteritidis isolated from spearmint (73.8\%). Salmonella enterica serovar Typhi isolates from lettuce and from the river water were $100 \%$ related to Salmonella enterica serovar Typhi isolated from the dam water.

In the antimicrobial sensitivity test, 14 out of $32(43.8 \%)$ isolated Salmonella strains were resistant to three or more of the antimicrobial groups (multidrug-resistant) (Table-4). The majority of isolates were sensitive to ceftriaxone, ciprofloxacin,

Table-3: Serotyping of Salmonella spp. isolated from Zarqa river water, King Talal dam water, vegetables, poultry, and livestock manure using multiplex PCR technique.

\begin{tabular}{lcccc}
\hline Sample sources & \multicolumn{2}{c}{ Serotypes $(\mathbf{n}=\mathbf{3 2})$} \\
\cline { 2 - 5 } & $\begin{array}{c}\text { Salmonella } \\
\text { enterica serovar } \\
\text { Typhi }(\mathbf{n = 3 )}\end{array}$ & $\begin{array}{c}\text { Salmonella } \\
\text { enterica serovar } \\
\text { Typhimurium }(\mathbf{n}=\mathbf{4})\end{array}$ & $\begin{array}{c}\text { Salmonella } \\
\text { enterica serovar } \\
\text { Enteritidis }(\mathbf{n}=\mathbf{2})\end{array}$ & $\begin{array}{c}\text { Salmonella } \\
\text { subspecies } \\
\text { I (n= 23) }\end{array}$ \\
\hline Zarqa River water & 1 & 0 & 0 & 2 \\
King Talal dam water & 1 & 0 & 1 & 4 \\
Vegetables & 1 & 1 & 1 & 11 \\
Poultry manure & 0 & 3 & 0 & 2 \\
Livestock manure & 0 & 0 & 0 & 4
\end{tabular}

Veterinary World, EISSN: 2231-0916 
Table-4: Antimicrobial sensitivity patterns of Salmonella spp. isolated from Zarqa river basin in Jordan $(n=32)$.

\begin{tabular}{|c|c|c|c|}
\hline \multirow[t]{2}{*}{ Antimicrobial agents } & \multicolumn{3}{|c|}{ Sensitivity patterns (\%) } \\
\hline & Sensitive & Intermediate & Resistant \\
\hline Ciprofloxacin (5 mg) & $30(93.8)$ & $2(6.3)$ & 0 \\
\hline Cefuroxime (3 $0 \mathrm{mg}$ ) & $28(87.5)$ & $3(9.4)$ & $1(3)$ \\
\hline $\begin{array}{l}\text { Sulfamethoxazole/ } \\
\text { trimethoprim }(23.75 / 1.25 \mathrm{mg})\end{array}$ & $20(62)$ & 0 & $12(37.5)$ \\
\hline Tetracycline $(30 \mathrm{mg})$ & $14(43.8)$ & $2(6.3)$ & $16(50)$ \\
\hline Nalidixic acid (30 mg) & $21(65.6)$ & $2(6.3)$ & $9(28)$ \\
\hline Chloramphenicol (30 mg) & $18(56)$ & 0 & $14(43.8)$ \\
\hline Ceftriaxone $(30 \mathrm{mg})$ & $31(97)$ & 0 & $1(3)$ \\
\hline Kanamycin (30 mg) & $22(68.8)$ & $7(21.9)$ & $9(28)$ \\
\hline Streptomycin (10 mg) & $20(62)$ & $2(6.3)$ & $10(31.3)$ \\
\hline Penicillin (10 IU) & $4(12.5)$ & $7(21.9)$ & $21(65.6)$ \\
\hline Gentamicin $(10 \mathrm{mg})$ & $27(84.4)$ & 0 & $5(15.6)$ \\
\hline Oxytetracycline (30 mg) & $7(21.9)$ & $4(12.5)$ & $21(65.6)$ \\
\hline Erythromycin (15 mg) & 0 & 0 & $32(100)$ \\
\hline Amoxicillin $(20 \mathrm{mg})$ & 0 & 0 & $32(100)$ \\
\hline
\end{tabular}

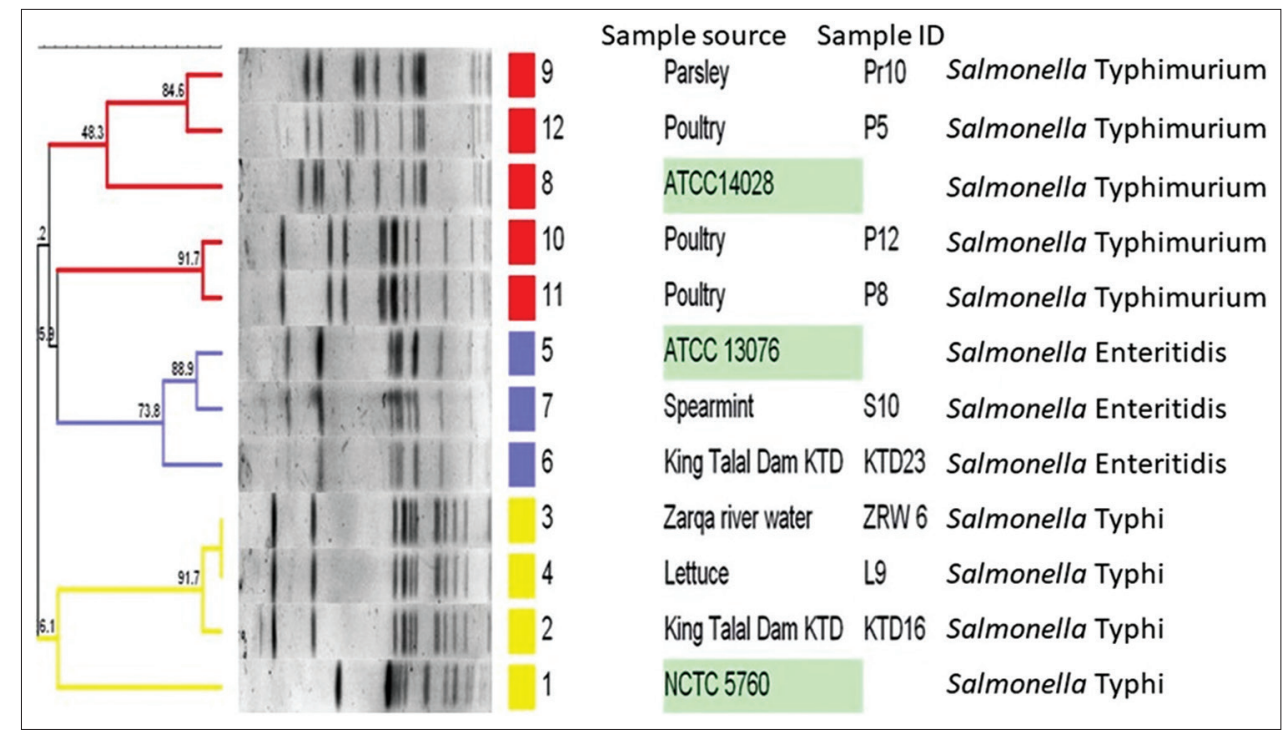

Figure-1: Phylogenic analysis of Salmonella spp. isolated from Zarqa River water, dam water, vegetables, and poultry manure showing two main clusters with close similarities between isolates from different sources.

cefuroxime, and gentamicin $(97 \%, 93.8 \%, 87.5 \%$, and $84.4 \%$, respectively). All isolates were resistant to erythromycin and amoxicillin.

\section{Discussion}

This is the first study to investigate the presence of Salmonella pathogens in two main surface water sources in Jordan used for irrigation of crops and leafy green vegetables and in adjacent livestock farms. Furthermore, the study determined the prevalence of different Salmonella serotypes, virulence characteristics, antimicrobial sensitivity patterns as well as their genetic relatedness and to determine the degree of cross-contamination. Overall, $12.8 \%(32 / 250)$ of all samples contained at least one serotype of pathogenic Salmonella spp. including Salmonella enterica serovar Typhimurium, Salmonella enterica serovar Typhi, and Salmonella enterica serovar Enteritidis or Salmonella subspecies I. In the current study, the rate of Salmonella spp. recovered from the water of Zarqa river and King Talal dam was $16 \%(8 / 50)$, which is higher than the incidence rate $(11 \%)$ of Salmonella contamination in surface water found in farms in New York State [17]. Surface water sources used for irrigation consistently appear to be a major reservoir for Salmonella spp. all over the world to a certain degree, the rate of which may be influenced by rainfall runoff and drainage from livestock farms, and wastewater management plants [18]. In this study, the relatively high rate of Salmonella spp. recovery from Zarqa River and King Talal dam may be attributed to dumping of treated wastewater from the nearby wastewater treatment plant, water runoffs from untreated or imperfectly treated wastes from towns and rural areas, and livestock farm wastes [19].

The rate of Salmonella spp. recovered in this study from poultry manure $(2.8 \%)$ was lower than that reported elsewhere in the world [20]. In a small ruminant research farm in Virginia State University, Salmonella spp. was detected in $3.5 \%$ of fecal samples which is higher than our finding [21]. It has been 
stated that the runoff water and waste from livestock farms to rivers and lakes and the use of contaminated animal manure as an organic fertilizer may results in cross-contamination of crops and vegetables with Salmonella spp. [1-4]. Moreover, it has been found that Salmonella can persist in the farm environment for extended periods of time due to circulation within the farm between different pools such as animals, livestock excrement, soil, and plants [22]. In this study, $13 \%$ of leafy green vegetables were contaminated with Salmonella. These results are similar to previously reported data in Nigeria (13.9\%) [12]. The much lower isolation rate of Salmonella spp. (1.8\%) has been reported from leafy green vegetables in Catalonia, Spain [23]. On the other hand, in Egypt, the presence of Salmonella was found in $42 \%$ in lettuce, $29 \%$ in strawberries [24]. The contamination of leafy green vegetables planted in Zarqa river basin and Jordan valley is most likely due to irrigation from contaminated surface water of Zarqa river and King Talal dam. Furthermore, presence of untreated animal manure in Zarqa river basin may have contaminated the river water that ultimately results in leafy green vegetables contamination. Hence, improper manure handling can be an important cause of direct contamination of water supplies and indirectly contaminate irrigated vegetables.

In the current study, Salmonella enterica serovar Typhimurium, Salmonella enterica serovar Typhi, Salmonella enterica serovar Enteritidis, and Salmonella subspecies I were detected in manure, water, and leafy green vegetables and most of them were detected in summer (May to September). All Salmonella isolates were resistant to one or more major groups of antibiotics. However, none of the isolates carried the multidrug-resistant plasmid gene $(p C T)$. This is may be due to other intrinsic resistance factors. These results are closely similar to previously reported data where most Salmonella isolates recovered from surface water, manure, and leafy green vegetables were resistant to multiple antibiotics [7]. It has been reported that some bacteria spp. may develop resistance to multiple antibiotics by spontaneous mutations that may occur within certain chromosomes [25]. This type of mutation may then transmit vertically and horizontally under the effect of antibiotic selective pressure [25].

In this study, there was considerable relatedness between different Salmonella strains isolated from different sources. This may indicate the survival and persistence of this bacterium in contaminated water sources and animal manure with a very likely potential for cross-contamination to leafy green vegetables. These results are in complete agreement with those reported previously, where high relatedness was found between Salmonella isolates obtained from vegetables, water, animals, and human [26]. Similar results were also reported among Salmonella isolates obtained from food, environmental and clinical samples [27].

\section{Conclusion}

Results of this study showed that two of the major water sources in Jordan that are currently used to irrigate crops and used in livestock farms are contaminated with pathogenic strains of Salmonella spp. Genetic analysis in this study indicated that the use of animal manure as a fertilizer of upstream lands, rain, and waste water runoffs as potential sources of this bacteria. Therefore, the use of such low-quality surface water for irrigation of crops is considered a potential source of Salmonella cross-contamination to human food supply, including leafy green vegetables. This presents a real and serious threat to human health because of the high pathogenicity and multiple drug resistance characteristics of the isolated Salmonella strains. It is recommended to monitor the quality of wastewater, runoff water, and surface water sources used for irrigation of crops and vegetables in this region to prevent cross-contamination of human food with this pathogenic bacterial.

\section{Authors' Contributions}

YHT: study concept and design. AFA: sample collection and performed laboratory testing. ZBI: scientific advice, data interpretation, and manuscript writing. All authors read and approved the final manuscript.

\section{Acknowledgments}

This project was funded by the Jordan University of Science and Technology Deanship of Research (Grant No. 2015/291).

\section{Competing Interests}

The authors declare that they have no competing interests.

\section{Publisher's Note}

Veterinary World remains neutral with regard to jurisdictional claims in published institutional affiliation.

\section{References}

1. Gutierrez-Rodriguez, E. and Adhikari, A. (2018) Preharvest farming practices impacting fresh produce safety. Microbiol. Spectr., 6(2): PFS-0022-2018.

2. Julien-Javaux, F., Gerard, C., Campagnoli, M. and Zuber, S. (2019) Strategies for the safety management of fresh produce from farm to fork. Curr. Opin. Food Sci., 27(1): 145-152.

3. Machado-Moreira, B., Richards, K., Brennan, F., Abram, F. and Burgess, C.M. (2019) Microbial contamination of fresh produce: What, where, and how? Compr. Rev. Food Sci. Food Saf., 18(6): 1727-1740.

4. Alegbeleye, O.O., Singleton, I. and Sant'Ana, A. S. (2018) Sources and contamination routes of microbial pathogens to fresh produce during field cultivation: A review. Food Microbiol., 73: 177-208.

5. Tegegne, F.M. (2019) Epidemiology of Salmonella and its serotypes in human, food animals, foods of animal origin, animal feed and environment. J. Food Nutr. Health, 2(1): 7-14.

6. Abebe, E., Gugsa, G. and Ahmed, M. (2020) Review on major food-borne zoonotic bacterial pathogens. J. Trop. 
Med., 2020: 4674235.

7. Abakpa, G.O., Umoh, V.J., Ameh, J.B., Yakubu, S.E., Kwaga, J.K.P. and Kamaruzaman, S. (2014) Diversity and antimicrobial resistance of Salmonella enterica isolated from fresh produce and environmental samples. Environ. Nanotechnol. Monit. Manag., 3: 38-46.

8. Heredia, N. and García, S. (2018) Animals as sources of food-borne pathogens: A review. Anim. Nutr., 4(3): 250-255.

9. Addis, M. and Sisay, D. (2015) A review on major foodborne bacterial illnesses. J. Trop. Dis., 3(4): 1-7.

10. Siroli, L., Patrignani, F., Serrazanetti, D.I., Tabanelli, G., Montanari, C., Gardini, F. and Lanciotti, R. (2015) Lactic acid bacteria and natural antimicrobials to improve the safety and shelf-life of minimally processed sliced apples and lamb's lettuce. Food Microbiol., 47: 74-84.

11. Mathole, M.A., Muchadeyi, F.C., Mdladla, K., Malatji, D.P., Dzomba, E.F. and Madoroba, E. (2017) Presence, distribution, serotypes and antimicrobial resistance profiles of Salmonella among pigs, chickens and goats in South Africa. Food Control, 72: 219-224.

12. Abakpa, G., Umoh, V., Ameh, J., Yakubu, S., Kwaga, J. and Ibekwe, A. (2015) Occurrence of enteric pathogens on fresh produce grown on irrigated soils. Br. Microbiol. Res. J., 6(1): 13-23.

13. Abdelhai, M.H., Hassanin, H.A.M. and Sun, X. (2016) Comparative study of rapid DNA extraction methods of pathogenic bacteria. Am. J. Biosci Bioeng., 4(1): 1-8.

14. Ben Abdallah, F., Lagha, R., Said, K., Kallel, H. and Gharbi, J. (2014) Detection of cell surface hydrophobicity, biofilm and fimbriae genes in Salmonella isolated from Tunisian clinical and poultry meat. Iran. J. Public Health, 43(4): 423-431.

15. Park, S.H., Kim, H.J., Cho, W.H., Kim, J.H., Oh, M.H., Kim, S.H., Lee, B.K., Ricke, S.C. and Kim, H.Y. (2009) Identification of Salmonella enterica subspecies I, Salmonella enterica serovars Typhimurium, enteritidis and Typhi using multiplex PCR. FEMS Microbiol. Lett., 301(1): 137-146.

16. Clinical and Laboratory Standards Institute. (2019) Performance Standards for Antimicrobial Susceptibility Testing, CLSI Supplement No. M100. 29th ed. CLSI, Wayne, Pennsylvania, USA. .

17. Strawn, L.K., Fortes, E.D., Bihn, E.A., Nightingale, K.K., Gröhn, Y.T., Worobo, R.W., Wiedmann, M. and Mergholz, P.W. (2013) Landscape and meteorological factors affecting prevalence of three food-borne pathogens in fruit and vegetable farms. Appl. Environ. Microbiol., 79(2): 588-600.

18. Pagadala, S., Marine, S.C., Micallef, S.A., Wang, F., Pahl, D.M., Melendez, M.V. and Buchanan, R.L. (2015) Assessment of region, farming system, irrigation source and sampling time as food safety risk factors for tomatoes. Int. J. Food Microbiol., 196: 98-108.

19. Mustafa, D., Altz-Stamm, A. and Scott, L.M. (2016) Water user associations and the politics of water in Jordan. World Dev., 79(3): 164-176.

20. Phagoo, L. and Neetoo, H. (2015) Antibiotic resistance of Salmonella in poultry farms of Mauritius. J. Worlds Poult. Res., 5(3): 42-47.

21. Pao, S., Hagens, B.E., Kim, C., Wildeus, S., Ettinger, M.R., Wilson, M.D. and Luchansky, J.B. (2014) Prevalence and molecular analyses of Campylobacter jejuni and Salmonella spp. in co-grazing small ruminants and wild-living birds. Livest. Sci., 160(1): 163-171.

22. Kupriyanov, A., Semenov, M., Bruggen, H.C. and van Bruggen, A.H.C. (2010) Transition of enteropathogenic and saprotrophic bacteria in the niche cycle: Animalsexcrement-soil-plants-animals. Biol. Bull., 37(3): 263-267.

23. Abadias, M., Usall, J., Anguera, M., Solsona, C. and Viñas, I. (2008) Microbiological quality of fresh, minimally-processed fruit and vegetables, and sprouts from retail establishments. Int. J. Food Microbiol., 123(1-2): 121-129.

24. Uyttendaele, M., Moneim, A.A., Ceuppens, S. and El Tahan, F. (2014) Microbiological safety of strawberries and lettuce for domestic consumption in Egypt. J. Food Proc. Technol., 5(3): 308.

25. Cox, G. and Wright, G.D. (2013) Intrinsic antibiotic resistance: Mechanisms, origins, challenges and solutions. Int. J. Med. Microbiol., 303(6-7): 287-292.

26. Thong, K.L., Goh, Y.L., Radu, S., Noorzaleha, S., Yasin, R., Koh, Y.T. and Puthucheary, S.D. (2002) Genetic diversity of clinical and environmental strains of Salmonella enterica serotype Weltevreden isolated in Malaysia. J. Clin. Microbiol., 40(7): 2498-2503.

27. Mezal, E.H., Sabol, A., Khan, M.A., Ali, N., Stefanova, R. and Khan, A.A. (2014) Isolation and molecular characterization of Salmonella enterica serovar Enteritidis from poultry house and clinical samples during 2010. Food Microbiol., 38: 67-74. 